\title{
Expression of fluorescent reporter protein was not obtained in ovine embryos produced through in vitro fertilization-sperm mediated gene transfer (IVF-SMGT)
}

\author{
Ramin Hasanzadeh ${ }^{1}$, Mohammad Zandi ${ }^{1 *}$, Mohammad Reza Sanjabi ${ }^{1}$, Khosro \\ Hoseini Pajooh $^{2}$, Hossin Shabani ${ }^{1}$ \\ 1. Department of Agriculture, Iranian Research Organization for Science and \\ Technology (IROST), P. O. Box 33535111, Tehran, Iran \\ 2. Department of Biotechnology, Iranian Research Organization for Science \\ and Technology (IROST), P. O. Box 33535111, Tehran, Iran \\ * Corresponding author. Email: mz1075@yahoo.com Tel/Fax: \\ +982156276639
}

Abstract

Sperm mediated gene transfer (SMGT) has been reported to be a powerful tool for producing transgenic animals on a mass scale using spermatozoa as vectors for exogenous DNA. In this study the possibility of using in vitro fertilization (IVF) -SMGT to produce transgenic ovine embryos was investigated for the first time. For this purpose, sperm were obtained from the epididymal testicle areas of 4 rams and different concentration of DNA $(0.4,0.8$ and $1.6 \mu \mathrm{g})$ and TurboFect $(0.25,0.5,1$ and $2 \mu \mathrm{g})$ were used for sperm transfection $\left(1 \times 10^{6}\right)$. Enhanced-GFP-expressing vector pEGFP-N1 was used as the carrier. In order to evaluate the performance of transgenic sperm, in vitro fertilization technology was used. After the preparing oocytes received from the ovaries of slaughterhouse origin, oocytes with more than three layers of granulosa and uniform cytoplasm were selected and matured in TCM-199 medium containing $10 \%$ fetal calf serum, follicle stimulating hormone (FSH) $(5 \mu \mathrm{g} / \mathrm{ml})$, $\beta-17$ estradiol $(1 \mu \mathrm{g} / \mathrm{ml})$ and sodium pyruvate $0.81(\mathrm{Mm})$. Bracket and Oliphant's (BO) medium and modified Charles Rosenkrans medium with amino acids (mCR2aa) were used for in vitro fertilization and culture, respectively. Results showed that transfected sperm with different concentrations of DNA and TurboFect carrier were unable to transfer the GFP gene to in vitro matured oocytes as the GFP gene was not expressed in neither zygotes nor morula stage embryos. Further optimization for SMGT improvement such as different transfection reagent and method like electroporation, using antioxidants in transfection medium to overcome the apoptosis and also separation of transfected sperm from untransfected ones before insemination have been suggested.

\section{Research highlights}

Transfected sperm with different concentrations of DNA and TurboFect carrier were unable to transfer the GFP gene to in vitro matured ovine oocytes. By increasing the amount of DNA, the expression of GFP gene was improved in fibroblast cells.

The mean number of zygote and morula stage embryos significantly decreased, by increasing the amount of TurboFect. 
Keywords: SMGT, Gene transfer, IVF and TurboFact

\section{Introduction}

Transgenic livestock production is of particular interest in agriculture and biomedicine (Zaniboni et al., 2016). The first transgenic livestock was produced in 1985 by microinjection of foreign DNA into zygotic pronuclei. This was the method of choice for more than 20 years (Kues and Niemann, 2011), and transgenic mice, sheep, pigs, and cattle have been successfully produced using this technique (Garcia-Vazquez et al., 2009), but besides being expensive, this technique is still inefficient when used to generate transgenic farm animals (0.5-4\%) (Garcia-Vazquez et al., 2011). More efficient protocols are now available (Kues and Niemann, 2011), including virus-mediated transgenesis, somatic cell nuclear transfer (SCNT) and sperm mediated gene transfer (SMGT) (Zaniboni et al., 2016). These methods vary in efficacy and safety. Technical and safety considerations limit the use of viral methods, especially in agricultural applications. In addition, the efficiency of non-viral methods, compared to viral methods is very low (Katebi et al., 2016).

Since 1971 there is evidence that a "heterologous genome" can be incorporated into a mammalian spermatozoon. Twenty years later it was shown that circular DNA can be incorporated into mouse epididymal spermatozoa by simple incubation and can be transmitted to oocytes resulting in the creation of transgenic animals (Hoelker et al., 2007). SMGT is based on the ability of sperm cells to bind, internalize and transport exogenous DNA into an oocyte during the process of fertilization, so uses sperm as a natural vector to transfer transgenes (Lavitrano et al., 1989; Kang et al., 2008; GarciaVazquez et al., 2011). However, the theory has not been well documented in different laboratories across the globe (Eghbalsaied et al., 2015).

The SMGT method, if proved to be reproducible, would be the simplest, costeffective, most rapid and mass gene transfer method to produce transgenic farm animals (Hoelker et al., 2007; Feitosa et al., 2010; Katebi et al., 2016). The SMGT strategy with the use of sex-sorted semen can also be an attractive approach to the generation of genetically-transformed male and female embryos/progeny derived from in vitro or in vivo fertilization (Zaniboni et al., 2016).

Although previous studies have resulted in the creation of transgenic animals in several species, including some invertebrate and insects, amphibians, fish, chicken, mouse, pigs and cattle, effectiveness remained low (Hoelker et al., 2007; Lanes et al., 2009; Bacci et al., 2009). Several factors determine the success of SMGT including the donors of spermatozoa, incubation media, exogenous DNA size and type and the assisted reproductive technique used (Garcia-Vazquez et al., 2011). DNA binding efficiency varies widely ranging from 0.3 to $78 \%$ among the sperm of different species. Consequently, the success rate of SMGT also varies in different animal species (Pramod et al., 2016). With respect to SMGT effectiveness both species specific effects and 
variability within individuals of one species were reported (Hoelker et al., 2007).

In order to improve the DNA uptake efficiency of sperm cells, several strategies have been employed, including treatment of spermatozoa with Triton-X (Hoelker et al., 2007), the use of chemical transfection reagents like liposomes (Bachiller et al., 1991) or DMSO (Shen et al., 2006), electroporation, monoclonal antibodies to link foreign DNA to the spermatozoa surface (Pramod et al., 2016) and restriction enzyme- mediated integration (REMI) (Camposa et al., 2011).

SMGT without intracytoplasmic sperm injection (ICSI) have not been reproduced to our knowledge in sheep. The aim of the current study was to examine the possibility of generating transgenic ovine embryo using sperm vector with the assistance of TurboFect transfection reagent.

\section{Material and methods}

2.1. Chemicals

All the culture media, growth factors, fetal bovine serum (FBS) and other chemicals were obtained from Sigma Chemical Co. (St. Louis, MO, USA) and the plasticware was purchased from Falcon (Paignton, UK) unless stated otherwise.

\subsection{Plasmid}

The enhanced green fluorescent protein (EGFP) plasmid construction (pEGFPN1, $5.4 \mathrm{~kb}$ ) used for our experiments contained the CMV promoter and the enhanced GFP gene. Plasmids were extracted using Plasmid Mega Kit (Qiagen) and the StuI restriction enzyme (Takara, Japan) was used to prepare linearized plasmid following the manufacturer's instructions and digestion efficiency was checked by $1 \%$ agarose gel electrophoresis.

2.3. Transfection of fibroblast cells

The ovine fibroblast cell line were established from sheep ear skin as described by Shah et al. (2008). One day before transfection, $0.5 \times 10^{5}$ of cells plated in $300 \mu \mathrm{l}$ of growth medium (DMEM, 10\% FBA and $50 \mu \mathrm{g} / \mathrm{ml}$ gentamicin) so that cells were $75 \%$ confluent at the time of transfection. In order to evaluation of vector, different concentration of DNA $(0.1,0.2,0.4$ and $0.8 \mu \mathrm{g})$ and TurboFect (Thermo Scientific/R0531) (0.5, 1 and $2 \mu \mathrm{g}$ ) were diluted in $50 \mu \mathrm{l}$ of transfection medium separately, and incubated for $5 \mathrm{~min}$ at room temperature. Then, the diluted DNA was added to diluted TurboFect (total volume $=100 \mu \mathrm{l}$ ) and incubated for $20 \mathrm{~min}$ at room temperature. $100 \mu \mathrm{l}$ of complexes was added to each well containing cells and mixed gently by rocking the plate back and forth. The cells were then incubated at $37^{\circ} \mathrm{C}$ in a humidified atmosphere of $5 \% \mathrm{CO}_{2}$ in air for $24 \mathrm{~h}$ prior to testing for transgene expression by fluorescence microscopy.

2.4. Collection of epididymal sperm

Four ram testes collected from a nearby abattoir slaughterhouse immediately after slaughter and were brought to the laboratory in an ice chest. In the 
laboratory, the testes were rinsed twice with normal saline and were then trimmed to remove the extra testicular tissue and washed properly with saline containing $0.1 \%$ streptomycin sulphate. Connective tissue covering the cauda epididymis was removed by careful dissection, with care to avoid rupturing blood vessels or the epididymal duct. Epididymal sperm collected as described by Garde et al. (1994). In summary, sperm was recovered from the cauda of epididymis by injecting PBS retrogradely through the ductus deferens. Collected sperm was washed once by centrifugation with PBS medium at 600 $\mathrm{g}$ for 7 minutes. The pellet obtained was suspended in BO media and evaluated for motility.

\subsection{Transfection of sperm}

In order to transfection of sperm, different concentration of DNA $(0.4,0.8$ and $1.6 \mu \mathrm{g})$ and TurboFect $(0.25,0.5,1$ and $2 \mu \mathrm{g})$ were diluted in $25 \mu \mathrm{l}$ of transfection medium separately, and incubated for $5 \mathrm{~min}$ at room temperature. Then, the diluted DNA was added to diluted TurboFect (total volume $=50 \mu \mathrm{l}$ ) and incubated for $20 \mathrm{~min}$ at room temperature. $1 \times 10^{6}$ sperm were added to 50 $\mu \mathrm{l}$ of DNA- TurboFect complexes and mixed gently by rocking the plate back and forth. The cells were then incubated at $37^{\circ} \mathrm{C}$ in a $\mathrm{CO}_{2}$ incubator $\left(5 \% \mathrm{CO}_{2}\right.$ in air) for $20 \mathrm{~min}$ and added to $50 \mu \mathrm{l}$ of $\mathrm{BO}$ media containing matured ovine oocytes for in vitro fertilization.

\subsection{In vitro fertilization}

Sheep ovaries collected from a nearby abattoir were brought over to the laboratory in phosphate-buffered saline (PBS) containing $100 \mathrm{IU} / \mathrm{ml}$ penicillin and $50 \mathrm{mg} / \mathrm{ml}$ streptomycin at $30-34^{\circ} \mathrm{C}$ within $3 \mathrm{~h}$ of slaughter. Ovarian follicles of $2-8 \mathrm{~mm}$ diameter were aspirated using an 20-gauge needle attached to a 10-ml syringe to obtain cumulus-oocyte complexes (COCs). Those having more than 3 layers of compact unexpanded cumulus cells and homogenous evenly-granular ooplasm were transferred to 100- $\mu$ l droplets (15-20 COCs per droplet) of in vitro maturation (IVM) medium, which consisted of TCM-199 containing $10 \% \mathrm{FBS}, 10 \%$ buffalo follicular fluid, $5 \mathrm{mg} / \mathrm{ml}$ porcine $\mathrm{FSH}, 1$ $\mathrm{mg} / \mathrm{ml}$ oestradiol- $17 \beta, 0.81 \mathrm{mM}$ sodium pyruvate and $50 \mathrm{mg} / \mathrm{ml}$ gentamicin sulfate, and were cultured under mineral oil in a petri dish in a $\mathrm{CO}_{2}$ incubator $\left(5 \% \mathrm{CO}_{2}\right.$ in air) at $38.5^{\circ} \mathrm{C}$ for $24 \mathrm{~h}$. For in vitro fertilisation the oocytes were washed twice with BO medium and were transferred to 50- $\mu \mathrm{L}$ droplets (15-20 oocytes per droplet) of capacitation and fertilisation BO medium (washing BO medium containing $10 \mathrm{mg} / \mathrm{ml}$ fatty acid-free bovine serum albumin (BSA)). The spermatozoa were prepared for fertilisation as per the protocol established by Chauhan et al., (1997). Oocytes were then inseminated using a final concentration of $1 \times 10^{6}$ motile spermatozoa $\mathrm{ml}^{-1}$ and incubated under mineral oil in a $\mathrm{CO}_{2}$ incubator $\left(5 \% \mathrm{CO}_{2}\right.$ in air) at $38.5^{\circ} \mathrm{C}$ for $18 \mathrm{~h}$. The cumulus cells were then removed from the presumed zygotes, after which these were cultured in mCR2aa containing $0.6 \%$ BSA for $48 \mathrm{~h}$ in groups of 10 per droplet. Following this, the cleaved embryos obtained were cultured in the in 
vitro culture (IVC) medium (mCR2aa $+0.6 \% \mathrm{BSA}+10 \% \mathrm{FBS}$ ) for up to 4 days until morula were obtained, with a change of medium every $48 \mathrm{~h}$.

2.7. Evaluation of transgene EGFP expression in fibroblasts and embryos

During the period of in vitro culture, embryos were briefly exposed to blue light using an excitation filter at $488 \mathrm{~nm}$ and an emission filter at $530 \mathrm{~nm}$ to determine the expression of the EGFP gene at different stages of development. Transfected fibroblast cells were analysed $48 \mathrm{~h}$ after transfiction and embryos on days 1 and 4 after IVF.

2.8. Statistical analysis

Each experiment was replicated at least four times. Data were analysed with a statistical software program (SPSS 16, IBM, USA). Comparisons between multiple numeric datasets were performed using one-way ANOVA followed by Duncan multiple-range test. Results are expressed as mean \pm SEM, and statistical significance was accepted at $\mathrm{P}<0.05$.

\section{Results}

Evaluation of GFP vector and TurboFect complex using fibroblast cells

The TurboFect carrier that can be used to transfer foreign genes to a range of cells, including primary and hardly infected cells, are considered as a carrier in current study. For evaluation of GFP vector and TurboFect complex different concentration of DNA $(0.1,0.2,0.4$ and $0.8 \mu \mathrm{g})$ and TurboFect $(0.5,1$ and 2 $\mu \mathrm{l})$ were used. Results showed that by increasing the amount of DNA, the expression of GFP gene was improved (Figure 1). However, only $0.5 \mu \mathrm{l}$ of TurboFect was able to transfect fibroblast cells.

3.1. Evaluation of transfected sperm using in vitro fertilization technology

In order to transfiction of sperm, $0.25,0.5,1$ and $2 \mu \mathrm{l}$ of TurboFect and 0.4, 0.8 and $1.6 \mu \mathrm{g}$ of DNA for each of $1 \times 10^{6}$ sperm cells were used. The results of in vitro fertilization by use of transfected sperm were showed in table 1 . In vitro fertilization of ovine matured oocytes by transfected spermatozoa, with different concentration of TurboFect and DNA, were not successfully resulted to expression of GFP on zygote or morula stage embryos (Figure 2). The mean number of zygote and morula stage embryos significantly affected, by increasing the amount of TurboFect to 1 or $2 \mu 1(\mathrm{p}<0.05)$.

\section{Discussion}

Despite extensive research and investment to produce transgenic animals via SCNT and pronuclear microinjection technologies, there is a growing body of interest to implement the technique of SMGT as a simple, cost effective, and efficient alternative approach. SMGT experiments have been extensively performed in different species, including mice, rabbit, bovine, porcine, feline, and monkey (Lavitrano et al., 1989; Pereyra-Bonnet et al., 2008; Shadanloo et al., 2010). Despite the apparent simplicity of the method, many previous attempts to confirm SMGT efficiency have not achieved the desired result (Kang et al., 2008). 
Pereyra-Bonnet et al. (2008) reached transgenic ovine embryo using SMGT, by the assist of ICSI. However, in our study the GFP gene was not successfully expressed in embryos. To the best of our knowledge, expression of EGFP was not obtained by IVF-SMGT in sheep. Success using SMGT was only reported in some reports using techniques that require the spermatozoa to maintain full functionality to reach the oocyte during artificial insemination (AI) or IVF (Canovas et al., 2010).

Different parameters were affecting on SMGT efficiency, as a tool for gene transfer, including semen quality, DNA uptake, and efficiency of binding.

The quality of the semen sample and DNA uptake are dependent primarily on viability and motility of spermatozoa (Lavitrano et al., 2003). Semen quality depends on different breeds and also individuals within the same breed. For example, Huang et al. (2000) showed that semen quality is known to be better than in Large White or Duroc swine breeds.

Efficiency of binding depends on incubation time, DNA dose and kind of constructs (Canovas et al., 2010). Previous studies considered that sperm DNA binding could require an incubation time longer than 30 min (Camaioni et al., 1992; Sperandio et al., 1996). However, Canovas et al. (2010) results showed that bovine spermatozoa were able to bind exogenous DNA much more rapidly, and that in $30 \mathrm{~min}$, the binding process was complete. These results suggest that long incubations with exogenous DNA before fertilization is not necessary for maximal fertilization results, particularly when considering that prolonged incubation negatively affects sperm viability.

The previous study by using Rhodamine labeled plasmid showed that around $38 \%$ of ovine spermatozoa transfected by foreign DNA (Hoseini Pajooh et al., 2014). However, Canovas et al. (2010) reported that live spermatozoa can bind exogenous DNA to a maximum of around $15 \%$ of the sperm population, in contrast with previous reports by Garcia-Vazquez et al. (2009) in pigs whose showed that most of the exogenous DNA bound to dead cells. These contradictory results could reflect different DNA binding patterns between species (Canovas et al., 2010). Recent evaluation of sperm interaction with foreign DNA clearly confirmed that postacrosomal uptake signal exclusively takes place in disrupted membrane of immotile or dead sperm which are unable to perform fertilization through either IVF or AI procedures (Eghbalsaied et al., 2013, 2015).

Our results indicated that cleavage and development of embryos to morula stage were not affected by different concentration of DNA, which is in agreement with the reports of Sciamanna et al. (2000) and Shadanloo et al. (2010) in caprine and mice, respectively. These results confirmed by Rieth et al. (2000) and Hoelker et al. (2007) when they used cleavage rate as marker. So the fertilizing capacity of sperm was not affects when incubated with exogenous DNA. Although, it was significantly decreased by increasing the concentration of transfection reagent. 
Canovas et al. (2010) explained that sperm carrying exogenous DNA are at a disadvantage when fertilizing the oocyte compared to sperm without DNA. It has been reported that incubation with exogenous DNA led to a significant decrease in sperm motility (Kang et al., 2008). The apoptotic cascade that is triggered after contact with exogenous DNA could be one another disadvantage. In this case, the majority of oocytes would be fertilized by sperm without exogenous DNA, resulting in a high percentage of nontransgenic embryos (Canovas et al., 2010). Also Szczygiel et al. (2003) showed that foreign DNA can result in sperm chromosome disintegrity, which leads paternal DNA fragmentation and consequently to embryo arrest.

Both sperm immobilization and nuclease activation might indicate the presence of natural defences activated in the sperm after the binding of exogenous DNA. It is reasonable to suggest that poor reproducibility of SMGT might also be related with activation of such defences in sperm (Kang et al., 2008).

In conclusion, from these contradictory reports in different species, we concluded that, in those species with low DNA uptake, we need assist of ICSI for success in SMGT method, however it will affect on commercial application of SMGT, specially on ovine and bovine species. Further optimization such as different transfection reagent and method like electroporation, using antioxidants in transfection medium to overcome the apoptosis and also separation of transfected sperm from untransfected ones before AI or IVF have already been suggested for SMGT improvement in such species.

\section{Acknowledgments}

We would like to thank Dr. Majed Masoumian and Amir Hossin Ahadi for their helpful comments during the research. This project supported by Iran national science foundation. 


\section{References}

Bacci, M.L., Zannoni, A., De Cecco, M., Fantinati, P., Bernardini, C., Galeati, G., Spinaci, M., Giovannoni, R., Lavitrano, M., Seren, E., Forni, M., 2009. Sperm-mediated gene transfer-treated spermatozoa maintain good quality parameters and in vitro fertilization ability in swine. Theriogenology. 72, 1163-1170.

Bachiller, D., Schellander, K., Peli, J., Rüther, U., 1991. Liposome-mediated DNA uptake by sperm cells. Mol. Reprod. Dev. 30, 194-200.

Camaioni, A., Russo, M.A., Odorisio, T., Gandolfi, F., Fazio, V.M., Siracusa, G., 1992. Uptake of exogenous DNA by mammalian spermatozoa: Specific localization of DNA on sperm heads. J. Reprod. Fertil. 96, 203-212.

Camposa, V.F., de Leona, P.M.M., Komninoua, E.R., Dellagostinb, O.A., Deschampsa, J.C., Seixasc, F.K., 2011. Tiago CollaresNanoSMGT: Transgene transmission into bovine embryos using halloysite clay nanotubes or nanopolymer to improve transfection efficiency. Theriogenology. 76, 15521560 .

Canovas, S., Gutierrez-adan, A., Gadea, J., 2010. Effect of exogenous DNA on bovine sperm functionality using the Sperm Mediated Gene Transfer (SMGT) technique. Mol. Reprod. Dev. 77, 687-698.

Chauhan, M.S., Palta, P., Das, S.K., Katiyar, P.K., and Madan, M.L., 1997. Replacement of serum and hormone additives with follicular fluid in the IVM medium: effects on maturation, fertilization and subsequent development of buffalo oocytes in vitro. Theriogenology. 48, 461-469.

Eghbalsaied, S., Amini, H., Ghaedi, K., Pirestani, A., Nabizadeh, P., 2015. In vivo evaluation of ovine sperm/embryo ability in mediating transgenic lamb. Mid. East. Fert. Soc. J. 20, 295-296.

Eghbalsaied, S., Ghaedi, K., Laible, G., Hosseini, S.M., Forouzanfar, M., Hajian, M., Oback, F. Nasr-Esfahani, M.H., Oback, B., 2013. Exposure to DNA is insufficient for in vitro transgenesis of live bovine sperm and embryos. Reprod. 145, 97-108.

Feitosa, W.B., Mendes, C.M., Milazzotto, M.P., Rocha, A.M., Martins, L.F., Simões, R., Paula-Lopes, F.F., Visintin, J.A., Assumpção, M.E.O.A., 2010. Exogenous DNA uptake by bovine spermatozoa does not induce DNA fragmentation. Theriogenology. 74, 563-568.

Garcia-Vazquez, F.A., Garcia-Rosello, E., Gutierrez-Adan, A., Gadea, J., 2009. Effect of sperm treatment on efficiency of EGFP-expressing porcine embryos produced by ICSI-SMGT. Theriogenology. 72, 506-518.

Garcia-Vazquez, F.A., Ruiz, L.A., Grulln, S., de Ondiz, A., Gutiérrez-Adn, A., Gadea, J., 2011. Factors affecting porcine sperm mediated gene transfer. Res. Vet. Sci. 91, 446-453.

Garde, J., Aguado, M., Perez, S., Garrido, D., Perez-Guzman, M., Montoro, V., 1994. Physiological characteristics of epididymal spermatozoa from postmorten rams. Theriogenology. 41, 203. 
Hoelker, M., Mekchay, S., Schneider, H., Bracket, B.G., Tesfaye, D., Jennen, D., Tholen, E., Gilles, M., Rings, F., Griese, J., Schellander, K., 2007. Quantification of DNA binding, uptake, transmission and expression in bovine sperm mediated gene transfer by RT-PCR: Effect of transfection reagent and DNA architecture. Theriogenology. 67, 1097-1107.

Hoseini Pajooh, K., Tajik, P., Karimipour, M., 2014. Dynamics of interaction between ram sperm with plasmid carrying human lysozyme gene in SMGT. J. Comp. Pathobiol. 11, 1331-1344.

Huang, S.Y., Kuo, Y.H., Lee, Y.P., Tsou, H.L., Lin, E.C., Ju, C.C., Lee, W.C., 2000. Association of heat shock protein 70 with semen quality in boars. Anim. Reprod. Sci. 63, 231-240.

Kang, F.A., Hakimov, H., Ruiz, A., Friendship, R.M., Buhr, M., Golovan S.P., 2008. The negative effects of exogenous DNA binding on porcine spermatozoa are caused by removal of seminal fluid. Theriogenology. 70, 1288-1296.

Katebi, S., Esmaeili, A., Ghaedi, K., 2016. Static magnetic field reduced exogenous oligo nucleotide uptake by spermatozoa using magnetic nanoparticle gene delivery system. J. Magnetism. Magnetic. Mat. 402, 184189.

Kues, W.A., Niemann, H., 2011. Advances in farm animal transgenesis. Prev. Vet. Med. 102, 146-156.

Lanes, C.F.C., Sampaio, L.A., Marins L.F., Evaluation of DNase activity in seminal plasma and uptake of exogenous DNA by spermatozoa of the Brazilian flounder Paralichthys orbignyanus. Theriogenology. 71, 525-533.

Lavitrano, M., Camaioni, A., Fazio, V.M., Dolci, S., Farace, M.G., Spadafora, C., 1989. Sperm cells as vectors for introducing foreign DNA into eggs: genetic transformation of mice. Cell. 57, 717-23.

Lavitrano, M., Forni, M., Bacci, M.L., di Stefano, C., Varzi, V., Wang, H., Seren, E., 2003. Sperm Mediated Gene Transfer in pig: selection of donor boars and optimization of DNA uptake. Mol. Reprod. Dev. 64, 284-291.

Pereyra-Bonnet, F., Fernandez-Martin, R., Olivera, R., Jarazo, J., Vichera, G., Gibbons, A., Salamone, D., 2008. A unique method to produce transgenic embryos in ovine, porcine, feline, bovine and equine species. Reprod. Fertil. Develop. 20, 741-749.

Pramod, R.K., Kumar, R., Mitra, A., 2016. Transgenic expression of green fluorescent protein in caprine embryos produced through electroporation-aided sperm-mediated gene transfer. Gene. 15, 505-11.

Rieth, A., Pothier, F., Sirard, M.A., 2000. Electroporation of bovine spermatozoa to carry DNA containing highly repetitive sequences into oocytes and detection of homologous recombination events. Mol. Reprod. Dev. 57, 338-345.

Sciamanna, I., Piccoli, S., Barberi, L., Zaccagnini, G., Magnano, A.R., Giordano, R., Campedelli, P., Hodgson, C., Lorenzini, R., Spadafora, C., 
2000. DNA dose and sequence dependence in sperm-mediated gene transfer. Mol. Reprod. Dev. 56, 301-305.

Shadanloo, F., Najafi, M.H., Hosseini, S.M., Hajian, M., Forouzanfar, M., Ghaedi, K., Abedi, P., hosseini, S.O., Hosseini, L., Eskandari-Nasab, M., Nasr Esfahani, M.H., 2010. Sperm status and DNA dose play key roles in sperm/ICSI-mediated gene transfer in caprine. Mol. Reprod. Dev. 77, 868875.

Shah, R.A., George, A., Singh, M.K., Kumar, D., Chauhan, M.S., Manik, R., Palta, P., Singla, S.K., 2008. Hand-made cloned buffalo (Bubalus bubalis) embryos: comparison of different media and culture systems. Cloning Stem Cells. 10, 435-442.

Shen, W., Li, L., Pan, Q., Min, L., Dong, H., Deng, J., 2006. Efficient and simple production of transgenic mice and rabbits using the new DMSO-sperm mediated exogenous DNA transfer method. Mol. Reprod. Dev. 73, 589-94.

Sperandio, S., Lulli, V., Bacci, M.L., Forni, M., Maione, B., Spadafora, C., Lavitrano, M., 1996. Sperm-mediated DNA transfer in bovine and swine species. Anim. Biotechnol. 7, 59.

Szczygiel, M.A., Moisyadi, S., Ward, W.S., 2003. Expression of foreign DNA is associated with paternal chromosome degradation in intracytoplasmic sperm injection-mediated transgenesis in the mouse. Biol. Reprod. 68, 1903-1910.

Zaniboni, A., Merlo, B., Zannoni, A., Bernardini, C., Lavitrano, M., Forni, M., Mari, G., Bacci, M.L., 2013. Expression of fluorescent reporter protein in equine embryosproduced through intracytoplasmic sperm injection mediated genetransfer (ICSI-MGT). Anim. Reprod. Sci. 137, 53- 61.

Zaniboni, A., Spinaci, M., Zannoni, A., Bernardini, C., Forni, M., Bacci, M.L., 2016. $\mathrm{X}$ and $\mathrm{Y}$ chromosome-bearing spermatozoa are equally able to uptake and internalize exogenous DNA by sperm-mediated gene transfer in swine. Res. Vet. Sci. 104, 1-3. 
Table 1. The effect of transfected spermatozoa with different concentration of TurboFect and DNA on zygote or morula formation.

\begin{tabular}{ccccccc}
\hline Treatments & $\begin{array}{c}\text { TurboFect } \\
(\mu \mathrm{l})\end{array}$ & $\begin{array}{c}\text { DNA } \\
(\mu \mathrm{g})\end{array}$ & Oocytes & Zygote (\%) & Morula (\%) & $\begin{array}{c}\text { Zygotes and } \\
\text { morula } \\
\text { expressing } \\
\text { GFP }\end{array}$ \\
\hline & & & & & & \\
Control & 0 & 0 & 80 & $85.00 \pm 3.00^{\mathrm{a}}$ & $69.50 \pm 2.50^{\mathrm{a}}$ & 0 \\
1 & 0.25 & 0.4 & 80 & $86.50 \pm 1.50^{\mathrm{a}}$ & $70.00 \pm 3.00^{\mathrm{a}}$ & 0 \\
2 & 0.25 & 0.8 & 80 & $84.50 \pm 2.50^{\mathrm{a}}$ & $66.50 \pm 3.50^{\mathrm{a}}$ & 0 \\
3 & 0.25 & 1.6 & 80 & $88.00 \pm 3.00^{\mathrm{a}}$ & $71.50 \pm 2.50^{\mathrm{a}}$ & 0 \\
4 & 0.5 & 0.4 & 80 & $80.50 \pm 0.50^{\mathrm{ab}}$ & $66.50 \pm 3.50^{\mathrm{a}}$ & 0 \\
5 & 0.5 & 0.8 & 80 & $85.50 \pm 2.50^{\mathrm{a}}$ & $69.00 \pm 2.00^{\mathrm{a}}$ & 0 \\
6 & 0.5 & 1.6 & 80 & $89.00 \pm 2.00^{\mathrm{a}}$ & $70.50 \pm 1.50^{\mathrm{a}}$ & 0 \\
7 & 1 & 0.4 & 80 & $69.50 \pm 2.50^{\mathrm{c}}$ & $56.00 \pm 3.00^{\mathrm{c}}$ & 0 \\
8 & 1 & 0.8 & 80 & $73.00 \pm 3.00^{\mathrm{bc}}$ & $54.00 \pm 2.50^{\mathrm{c}}$ & 0 \\
9 & 1 & 1.6 & 80 & $71.00 \pm 3.00^{\mathrm{c}}$ & $50.50 \pm 2.50^{\mathrm{bc}}$ & 0 \\
10 & 2 & 0.4 & 80 & $58.50 \pm 4.50^{\mathrm{d}}$ & $40.50 \pm 3.50^{\mathrm{d}}$ & 0 \\
11 & 2 & 0.8 & 80 & $55.00 \pm 3.00^{\mathrm{d}}$ & $40.00 \pm 2.00^{\mathrm{d}}$ & 0 \\
12 & 2 & 1.6 & 80 & $59.00 \pm 4.00^{\mathrm{d}}$ & $45.50 \pm 2.50^{\mathrm{d}}$ & 0 \\
\hline
\end{tabular}

${ }^{a, b, c}$ Different letters indicate statistical difference within each column $(\mathrm{P}<0.05)$.

Data is expressed as mean \pm SEM of four replicates. 


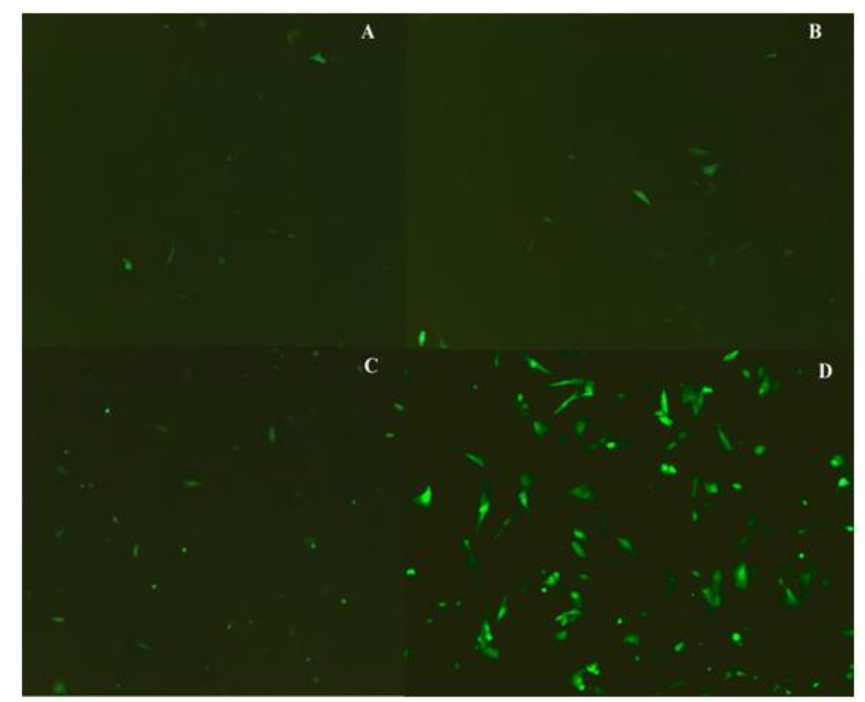

Figure 1. Optimization of DNA concentration for transfiction of fibroblast cells with $0.5 \mu 1$ TurboFect. A) $0.1 \mu \mathrm{g}$ DNA, B) $0.2 \mu \mathrm{g}$ DNA, C) $0.4 \mu \mathrm{g}$ DNA and D) $0.8 \mu \mathrm{g}$ DNA

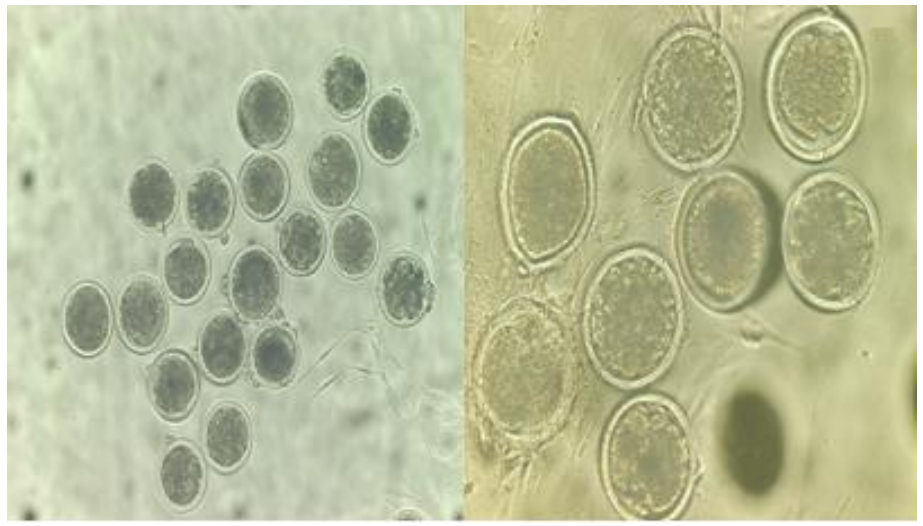

Figure 2. Morula stage embryos by using transfected spermatozoa, GFP expression could not be detected on them. 